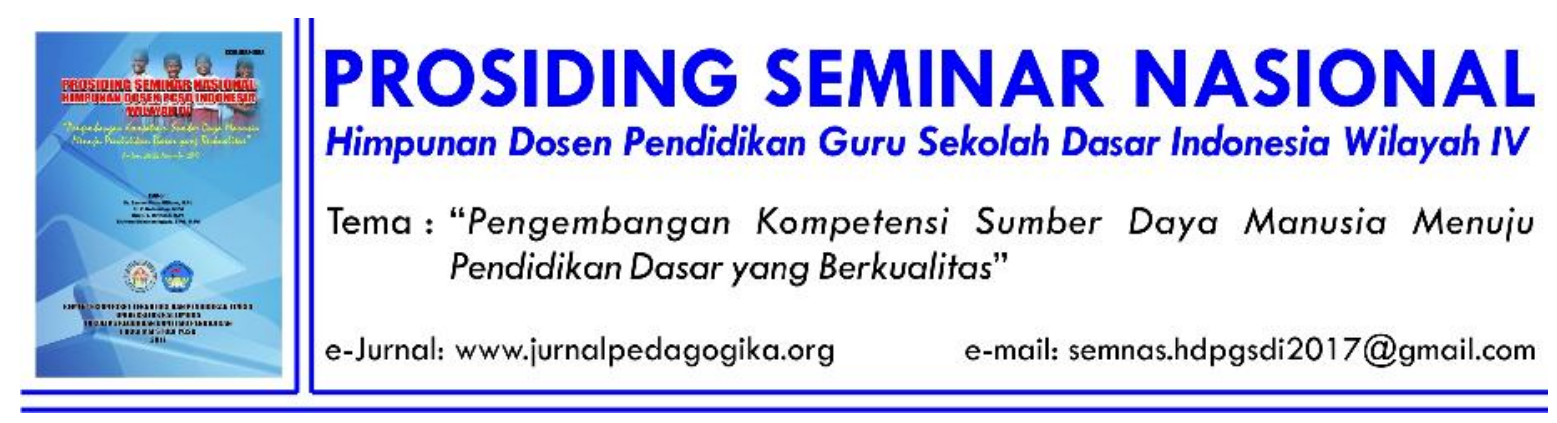

\title{
PENGEMBANGAN BAHAN AJAR TEMATIK TERPADU DI KELAS V SEKOLAH DASAR MENGGUNAKAN IDENTIFIKASI MASALAH
}

\author{
Desyandri ${ }^{1, a}$; Dori Vernanda ${ }^{2}$ \\ ${ }^{1}$ Dosen Universitas Negeri Padang; ${ }^{2}$ Guru Sekolah Dasar, Kota Pariaman \\ e-mail: desyandri@fip.unp.ac.id
}

\begin{abstract}
This research goals was to be achieved in the development of these materials is to produce an integrated thematic teaching materials are valid, practical, and effective. This research is a type of development and uses ADDIE models which consists of five phases: Analysis, Design, Development, Implementation, and Evaluation phases. Test the validity of research data obtained through the sheet validity of teaching materials. Data obtained through the sheet practicality of the implementation of lesson plans, teacher response assessment and student response assessment. Effectiveness seen from the student activity, assessment process and assessment of results.Based on the validity of test data showed that the average percentage of the teaching materials validator is $89.26 \%$ with the category of very valid. The test results practicalities of the implementation of the lesson plan obtained $91.43 \%$ with a very good category. Rating teacher responses obtained $93.05 \%$ and $89.58 \%$ student response. The effectiveness of teaching materials seen from the student activity, obtained an average percentage of $85.67 \%$ with a very active category. Of the daily assessment conducted seen tends to increase student learning outcomes. Based on these results, we can conclude an integrated thematic teaching materials Elementary School fifth grade using Problem Based Learning developed can be considered valid, practical, and efficient.
\end{abstract}

Key Words : Teaching Materials; Integrated; Thematic; Learning.

\section{PENDAHULUAN}

Dunia pendidikan pada saat ini memiliki banyak tuntutan dan tantangan. Salah satu adalah pendidikan, pendidikan hendaknya mampu menghasilkan sumber daya manusia yang memiliki kompetensi yang utuh, yaitu kompetensi sikap, kompetensi pengetahuan, dan kompetensi keterampilan yang terintegrasi. Menurut Siswoyo dkk, (dalam Pratowo, 2013:21) "siswa guru dan tujuan pendidikan merupakan komponen sentral dalam pendidikan.

Kurikulum 2013 untuk Sekolah Dasar (SD), bersifat tematik terpadu. Proses 
pembelajaran menekankan pada aspek spiritual, sosial, pengetahuan, dan keterampilan melalui penilaian tes dan portofolio saling melengkapi.

Buku teks pelajaran pada kurikulum 2013 khususnya pada jenjang pendidikan SD, sudah disediakan oleh pemerintah. Buku teks pelajaran berupa buku pedoman guru dan buku pedoman siswa.

Harapan pemerintah dengan adanya buku pedoman guru dan buku pedoman siswa, dapat mempermudah guru menyampaikan pesan pembelajaran, meningkatkan aktivitas dan kreatifitas siswa dalam proses pembelajaran.

Kondisi di lapangan menunjukan kenyataan yang berbeda, tidak semua rancangan pemerintah berjalan sesuai dengan rencana. Guru dan siswa mengalami beberapa permasalahan saat melaksanakan kurikulum 2013, khusus permasalahan dalam proses pembelajaran, permasalahan pertama, adalah pembelajaran masih berpusat pada guru. Permasalahan kedua, adalah kurangnya kesempatan siswa memperoleh pengalaman langsung baik mengamati, menanya, mencobakan, mengolah informasi, dan mengkomunikasikan. Permasalahan ketiga, yang sering terjadi adalah saat pembelajaran berlangsung kebanyakan guru monoton. Permasalahan keempat, sebagian siswa belum aktif selama proses pembelajaran. Permasalahan kelima, sebagian guru dalam proses pembelajaran masih menggunakan metode ceramah, sedangakan pada kurikulum 2013 ada beberapa model yang bisa digunakan saat proses pembelajaran, seperti Pembelajaran Berbasis Masalah, Discovery Learning, dan Pembelajaran Berbasis Proyek.

Berdasarkan latar belakang diatas rumusan masalah penelitian diungkapkan sebagai berikut: 1. Sebagian guru menjadikan buku guru dan buku siswa sebagai satusatunya sumber belajar, 2. Masih ada siswa yang kurang aktif dalam pembelajaran, 3. Guru kurang paham penggunaan buku guru dan buku siswa, 4. Bahan ajar yang digunakan kurang sesuai dengan indikator pembelajaran sehingga tujuan pembelajaran yang diharapkan tidak tercapai secara efektif, 5. Belum tersedianya bahan ajar sebagai sumber belajar lain yang memuat ide-ide guru yang disesuaikan dengan kondisi siswa serta lingkungan sekitar, 6. Kurang sesuainya materi pelajaran pada buku siswa dengan indikator yang ada pada buku guru.

Masalah dalam penelitian ini perlu dibatasi agar ada titik fokus yang menjadi studi kajian. Pembatasan masalah pada penelitian ini difokuskan pada aspek : 1. Pengembangan bahan ajar tematik terpadu, 2. Bahan ajar yang dikembangkan dibatasi untuk pembelajaran kelas $\mathrm{V}$ semester 1 .

Berdasarkan pembatasan masalah di atas, maka dapat dirumuskan permasalahan dalam penelitian ini adalah:

1. Bagaimana mengembangkan bahan ajar tematik terpadu di kelas $V$ sekolah dasar yang valid, praktis, dan efektif?

2. Bagaimana menghasilkan bahan ajar tematik terpadu yang valid, praktis, dan efektif?

Bahan ajar merupakan seperangkat materi yang disusun secara sistematis untuk membantu keterlaksanaan proses pembelajaran. Bahan ajar yang dikembangkan pada penelitian ini berupa seperangkat materi pembelajaran yang dikembangkan dengan strategi Pembelajaran Berbasis Masalah (problem-based learning). Secara spesifik, bahan ajar yang dikembangkan dapat dijabarkan sebagai berikut: 
1. Kelayakan isi

a. Memberikan gambaran $\mathrm{KI}, \mathrm{KD}$, indikator, dan tujuan pembelajaran yang jelas.

b. Menghasilkan petunjuk penggunaan bahan ajar bagi guru dan siswa.

c. Menghasilkan bahan ajar yang menggunakan bacaan sesuai dengan siswa kelas V SD.

d. Penjabaran setiap materi pelajaran sesuai dengan rumusan indikator.

e. Menghasilkan materi pelajaran yang akurat.

f. Menghasilkan bahan ajar yang memuat nilai-nilai moral dan sosial.

2. Kebahasaan

a. Dilengkapi peta konsep pemetaan materi sehingga dapat tergambar secara jelas cakupan materi pembelajaran secara umum.

b. Dilengkapi dengan petunjuk-petunjuk yang jelas dalam menyelesaikan tugastugas.

3. Penyajian

a. Materi yang dijabarkan menggambarkan tahapan Pembelajaran Berbasis Masalah (problem-based learning).

b. Dilengkapi dengan lembar kegiatan kerja siswa untuk mengukur kemampuan siswa.

c. Dilengkapi dengan uji kompetensi untuk mengukur kemampuan siswa dalam memahami isi bacaan melalui tahapan Pembelajaran Berbasis Masalah yang digunakan.

d. Diberikan refleksi diri tentang materi yang sudah dan belum dipahami sehingga memberikan kesempatan kapada siswa untuk memahami materi lebih lanjut.

4. Kegrafikan

a. Cover bahan ajar didesain sesuai dengan materi pembelajaran,

b. Dilengkapi dengan gambar dan sajian warna didominasi oleh warna hijau dan kuning yang menarik sehingga dapat menarik minat siswa untuk membaca bahan ajar yang dikembangkan.

c. Pembuatan bahan ajar menggunakan Microsoft Office Word 2007 dengan jenis font Arial Narrow ukuran 13.

d. Menggunakan icon dan gambar-gambar yang mencerminkan kegiatan belajar.

Hasil pengembangan bahan ajar ini diharapkan dapat memberikan manfaat sebagai berikut :

1. Bahan ajar untuk siswa kelas $V$ ini diharapkan dapat digunakan sebagai contoh bahan ajar untuk pembelajaran tematik terpadu di kelas lainnya.

2. Bagi siswa, dapat membantu siswa dalam meningkatkan pemahamannya terhadap muatan pembelajaran yang terjaring dalam satu pembelajaran dan dapat digunakan sebagai sumber belajar.

3. Bagi guru, sebagai salah satu perangkat dalam pelaksanaan pembelajaran tematik terpadu di sekolah.

Agar hasil pengembangan lebih optimal dan terarah, maka ada asumsi dan keterbatasan dalam pengembangan sebagai berikut:

1. Asumsi Pengembangan 
a. Pembelajaran dengan menggunakan bahan ajar tematik terpadu meningkatkan keaktifan belajar siswa.

b. Proses pembelajaran akan lebih efektif, efisien, dan lebih berkualitas dengan menggunakan bahan ajar tematik terpadu.

c. Pengembangan bahan ajar ini dapat memberikan pembelajaran yang lebih bervariasi, menarik, dan mudah dipahami oleh siswa.

2. Keterbatasan Pengembangan

Keterbatasan penelitian pengembangan ini dapat dibatasi pada aspek berikut ini:

a. Perangkat pembelajaran yang dikembangkan adalah bahan ajar tematik terpadu dengan strategi Pembelajaran Berbasis Masalah (problem-based learning).

b. Bahan ajar yang dikembangkan dibatasi untuk pembelajaran satu subtema kelas $V$ semester 1 , yaitu subtema 2 pada tema 4 .

Ada beberapa istilah yang perlu diperhatikan sebagai dasar pemahaman terhadap penelitian pengembangan yang akan dilakukan, agar tidak menimbulkan perbedaan penafsiran istilah. Beberapa istilah itu dijabarkan sebagai berikut:

1. Bahan ajar adalah segala bentuk bahan yang digunakan untuk membantu guru dalam melaksanakan proses pembelajaran di kelas. Bahan yang dimaksud adalah bahan ajar tertulis.

2. Rancangan Pengembangan Bahan Ajar Model ADDIE

Salah satu model desain pembelajaran yang sifatnya lebih generik adalah model ADDIE (Analysis-Design-Develop-Implement-Evaluate). ADDIE muncul pada tahun 1990-an yang dikembangkan oleh Reiser dan Mollenda. Salah satu fungsinya ADIDE yaitu menjadi pedoman dalam membangun perangkat dan infrastruktur program pelatihan yang efektif, dinamis dan mendukung kineria pelatihan itu sendiri.

3. Strategi strategi Pembelajaran Berbasis Masalah (problem-based learning) adalah suatu pendekatan pembelajaran yang dimulai dengan menyelesaikan suatu masalah, tetapi untuk menyelesaikan masalah itu siswa memerlukan pengetahuan baru untuk dapat menyelesaikannya.

4. Validitas bahan ajar merupakan adalah kesahihan sesuatu yang diukur. Validitas ini terdiri atas validitas isi dan validitas konstruksi yang dilakukan oleh validator dosen dan guru melalui angket pengujian validitas.

5. Praktikalitas bahan ajar merupakan tingkat kepraktisan dari sudut pandang guru dan siswa, dan didapat berdasarkan komentar atau pendapat dari guru dan siswa terhadap bahan ajar yang dihasilkan.

6. Efektivitas bahan ajar merupakan pengujian yang harus dilakukan terhadap bahan ajar yang telah dikembangkan, dalam hal ini efektifitas dilihat dari aktivitas siswa dan hasil belajar siswa setelah mempelajari bahan ajar yang telah dikembangkan.

Penelitian dan pengembangan atau dalam bahasa inggrisnya disebut Research and Development adalah metode penelitian yang digunakan untuk menghasilkan produk tertentu dan menguji keefektifan produk tersebut disampaikan oleh Sugiyono (2012: 407). Pengertian pengembangan menurut Borg \& Gall (1983) (dalam Setyosari 2015: 276) adalah "suatu proses yang dipakai untuk mengembangkan dan memvalidasi produk pendidikan". 
Penelitian pengembangan sebagai salah satu metode dalam penelitian, penelitian pengembangan memiliki tujuan dalam penerapannya sebagaimana dikemukakan oleh Setyosari (2010:196) menjelaskan bahwa tujuan pelaksanaan penelitian pengembangan adalah untuk menilai perubahan-perubahan yang terjadi dalam kurun waktu melalui metode tertentu serta mengamati sekelompok subjek selama beberapa waktu.

Menurut Semiawan (2008:183), penelitian pengembangan bertujuan untuk menghasilkan suatu produk yang dianggap penting dan menunjukkan kepentingan yang layak dihasilkan dan diselenggarakan

Berdasarkan beberapa pendapat yang dikemukakan di atas, dapat disimpulkan bahwa penelitian pengembangan bertujuan untuk menghasilkan produk dengan memperhatikan tingkat kebutuhannya sehingga mampu menghasilkan sebuah produk yang efektif.

\section{KAJIAN TEORI}

\section{Model Penelitian Pengembangan}

Dalam pelaksanaan pendidikan, penelitian pengembangan memiliki model-model yang sesuai untuk diterapkan. Pada penelitian ini, penulis memilih model penelitian pengembangan ADDIE.

Model pengembangan ADDIE adalah model yang dikembangkan oleh S. Raiser dan Mollenda. Model pengembangan ini disusun secara terprogram dengan urutan-urutan kegiatan yang sistematis dalam upaya pemecahan masalah belajar yang berkaitan dengan sumber belajar yang sesuai dengan kebutuhan dan karakteristik siswa. Tahaptahap antara lain: analisis (analysis), perancangan (design), pengembangan (development), eksekusi (implement), umpan balik (evaluation).

Berdasarkan kebutuhan peneliti, maka model pengembangan yang akan dipakai pada penelitian ini adalah ADDIE karena model ini dianggap cocok dalam pengembangan bahan pembelajaran. Pemilihan model ini didasari atas pertimbangan bahwa model ini dikembangkan secara sistematis dan berpijak pada landasan teoritis desain pembelajaran.

\section{Pengertian Bahan Ajar}

Menurut Dwicahyono (2014: 171) "bahan ajar merupakan segala bentuk bahan berupa informasi, alat dan teks yang dipergunakan oleh seorang guru dalam kegiatan mengajar di kelas sehingga memudahkan siswa untuk belajar mandiri". Pendapat lain dikemukan oleh Prastowo (2013: 297) "bahan ajar merupakan seperangkat materi yang disusun secara sistematis, baik tertulis ataupun tidak, sehingga tercipta lingkungan atau suasana yang memungkinkan siswa untuk belajar".

\section{Fungsi Bahan Ajar}

Pengembangan bahan ajar memiliki dua fungsi pokok yakni bagi guru dan siswa. Adapun fungsi bahan ajar menurut Depdiknas (dalam Abidin, 2014: 263), "fungsi bahan ajar yakni: (1) sebagai pedoman bagi guru dalam pembelajaran, sekaligus merupakan substansi kopetensi yang seharusnya diajarkan kepada siswa, (2) pedoman bagi siswa, sekaligus merupakan substansi kopetensi yang seharusnya dipelajari oleh siswa, dan (3) sebagai alat evaluasi pencapaian hasil pembelajaran". 


\section{Jenis-Jenis Bahan Ajar}

Bahan ajar yang digunakan dalam pembelajaran memiliki berbagai bentuk yang dapat dikembangkan. Menurut Mulyasa (2006) dalam bukunya menyebutkan bahwa bentuk bahan ajar atau materi pembelajaran antara lain: (1) Bahan cetak seperti; modul, buku, LKS, brosur, hand out, leaflet, wallchart, (2) Audio Visual seperti; video/ film, VCD, (3) Audio seperti; radio, kaset, CD audio, PH, (4) Visual; foto, gambar, model/ maket, (5) Multi Media; CD interaktif, computer Based, Internet.

\section{Hakikat Pembelajaran Tematik Terpadu}

Menurut Ujang Sukandi, dkk. (2001: 3) (dalam Trianto 2010:56) "pembelajaran terpadu pada dasarnya dimaksudkan sebagai kegiatan mengajar dengan memadukan materi beberapa mata pelajaran dalam satu tema".

Pembelajaran tematik terpadu sering juga disebut dengan pembelajaran tematik-integratif . Menurut Sutirjo dan Sri Istuti Mamik (dalam Mulyoto, 2013: 118) “ pembelajaran tematik-integratif adalah pembelajaran yang mengintegrasikan materi beberapa mata pelajaran dalam satu tema pembahasan.

Dapat disimpulkan bahwa pembelajaran tematik terpadu merupakan pembelajaran yang menggunakan tema dengan mengaitkan beberapa mata pelajaran sehingga memberikan pembelajaran yang bermakna kepada siswa.

\section{Kurikulum 2013}

Pelaksanaan pembelajaran tematik terpadu diterapkan dalam pelaksanaan kurikulum 2013. Kurikulum 2013 dikembangkan berbasis pada kompetensi yang sangat diperlukan sebagai instrumen untuk mengarahkan siswa menjadi; (1) manusia berkualitas yang mampu dan proaktif menjawab tantangan zaman yang selalu berubah; (2) manusia terdidik yang beriman dan bertakwa kepada Tuhan Yang Maha Esa, berakhlak mulia, sehat, berilmu, cakap, kreatif, mandiri; dan (3) warga negara yang demokratis, bertanggung jawab (Buku Materi Pelatihan Guru Implementasi kurikulum 2013 Tahun 2014 SD Kelas V 2014).

\section{Hakikat Pembelajaran Berbasis Masalah}

Pembelajaran berbasis masalah menerapkan dan mengembangkan pembelajaran yang mampu mendorong siswa untuk dapat memahami tentang apa, mengapa suatu masalah terjadi dan bagaimana upaya siswa dalam mengatasi masalah tersebut. Pendapat Tan, 2000 (dalam Rusman 2012: 232) "Pembelajaran Berbasis Masalah merupakan penggunaan berbagai macam kecerdasan yang diperlukan untuk melakukan konfrontasi terhadap tantangan dunia nyata, kemampuan untuk menghadapi dunia nyata, kemampuan untuk menghadapi segala sesuatu yang baru dan kompleksitas yang ada".

\section{METODOLOGI PENELITIAN}

\section{Jenis Penelitian}

Jenis penelitian ini adalah penelitian pengembangan (development research). Penelitian pengembangan merupakan kegiatan pengumpulan, pengolahan, analisis, dan penyajian data yang dilakukan secara sistematis dan objektif. Pengembangan suatu produk untuk memecahkan suatu persoalan yang dihadapi.

Model Pengembangan 
Model pengembangan yang digunakan adalah model ADDIE, ADDIE muncul pada tahun 1990-an yang dikembangkan oleh Reiser dan Mollenda. Model pengembangan ADDIE ini dipilih, dikarenakan sesuai dengan masalah yang melatar belakangi penelitian ini. Adanya analisis kebutuhan, maka diharapkan model ini dapat mengembangkan bahan ajar untuk kelas $V$ Sekolah Dasar yang valid, praktis, dan efektif guna meningkatkan aktivitas belajar dan hasil belajar siswa. Model ini terdiri dari lima tahap yaitu analisis (analyze), perancangan (design), pengembangan (development), implementasi (implementation), evaluasi (evaluation).

\section{Subjek Uji Coba}

Subjek uji coba pada penelitian ini adalah siswa dan guru kelas V SDN 19 Kampung Baru Pariaman Tengah. Kriteria yang digunakan untuk memilih subjek uji coba adalah sebagai berikut:

1. Kondisi siswa sesuai dengan kebutuhan penelitian.

2. Lingkungan sekolah yang mendukung keterlaksanaan penelitian, sehingga dimungkinkan untuk mendapatkan data penelitian.

\section{Jenis Data}

Jenis data yang diambil dalam penelitian ini adalah data primer. Data pertama berupa hasil validasi bahan ajar yang diberikan validator. Data kedua diperoleh pada pelaksanaan uji coba. Pada uji coba ini diambil data berupa: (1) hasil observasi keterlaksanaan RPP dari observer, (2) hasil respon guru terhadap bahan ajar yang digunakan, (3) respon siswa setelah bahan ajar diujicobakan, dan (4) hasil belajar siswa yang ditinjau dari aspek keterampilan membaca dan hasil tes.

\section{Instrumen Penelitian Pengembangan}

Instrumen merupakan salah satu alat untuk pengumpulan data. Sarana pengumpulan data pada penelitian pengembangan ini adalah angket (qestionnaire). Angket (qestionnaire) digunakan untuk memperoleh data validitas, praktikalitas, dan efektifitas dari bahan ajar.

\section{Teknik Analisis Data}

Teknik analisis data yang digunakan adalah analisis data deskriptif, yaitu mendeskripsikan tingkat validitas bahan ajar, kepraktisan bahan ajar, kompetensi siswa yang menunjukkan efektivitas bahan ajar.

Hasil validasi dari validator terhadap seluruh aspek yang dinilai, disajikan dalam bentuk tabel. Untuk mengukur perhitungan dan nilai akhir hasil validitas digunakan rumus dari Muliyardi (2006: 82) yaitu sebagai berikut:

$$
R=\frac{\sum_{i=1}^{n} V_{i i}}{n m} \times 100
$$

\section{Keterangan :}




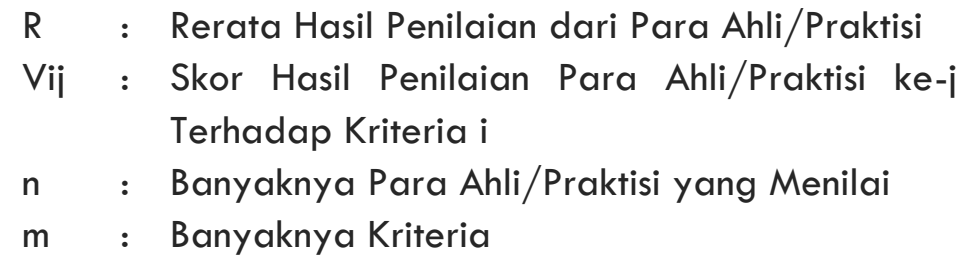

\section{HASIL DAN PEMBAHASAN}

Berikut dipaparkan hasil penelitian tentangpengembangan bahan ajar tematik terpadu kelas V SD menggunakan Pembelajaran Berbasis Masalah dengan model pengembangan ADDIE, diperoleh data hasil penelitian sebagai berikut:

1) Analisis (Analyze)

Pada tahap ini meliputi kegiatan sebagai berikut: (a) melakukan analisis kompetensi yang dituntut kepada siswa; (b) melakukan analisis karakteristik siswa tentang kapasitas belajarnya, keterampilan, sikap yang telah dimiliki siswa serta aspek lain yang terkait; (c) melakukan analisis materi sesuai dengan tuntutan kompetensi. Adapun analisis tersebut dipaparkan sebagai berikut:

a. Analisis Kompetensi yang dituntut kepada siswa

Pada tahap ini dilakukan telaah terhadap kompetensi apa saja yang dicapai siswa setelah menggunakan bahan ajar pengembangan dalam pembelajaran, baik itu sikap, pengetahuan, maupun keterampilan. Analisis KD pada subtema 2 menunjukkan KD-KD yang muncul pada muatan pembelajaran, dari hasil analisis dapat dilihat bahwa muatan pembelajaran bahasa Indonesia mucul pada pembelajaran 1 sampai 6. (hasil analisis dapat dilihat pada lampiran 1). Setelah melakukan analisis KD pada satu subtema selanjutnya yang dianalisis adalah penjabaran KD dan indikator dari hasil analisis terlihat beberapa KD tidak memiliki indikator, dan ada beberapa indikator yang disempurnakan, (hasil analisis dapat dilihat pada lampiran 2).

b. Analisis Karakteristik Siswa

Analisis karakteristik dilakukan untuk mengetahui keadaan siswa di kelas $V$ SD yang akan menjadi sasaran penggunaan bahan ajar. Keadaan siswa yang dimaksud antara lain: pengetahuan awal yang dimiliki, minat dan bakat secara umum, gaya belajar, dan kemampuan berbahasa.

c. Analisis Materi

Analisis materi merupakan tahap di mana peneliti menganalisis materi-materi apa saja yang perlu dikembangkan, baik itu materi-materi pokok, subbagian dari materi pokok dan anak subbagian, materi yang dianalisis disini adalah materi yang ada pada Kurikulum 2013 kelas V SD semester I pada tema 4 Sehat itu Penting. Berdasarkan kenyataan di lapangan, proses pembelajaran yang berlangsung kurang efektif. Pembelajaran yang terjadi juga hanya sebatas penerimaan informasi semata, tanpa adanya penekanan terhadap pengembangan nilai-nilai moral pada siswa. Siswa menganggap kegiatan pembelajaran sesuatu yang membosankan. Berdasarkan analisis tersebut, terlihat bahwa diperlukan pengembangan bahan ajar tematik terpadu kelas V SD menggunakan Pembelajaran Berbasisi Masalah. Bahan ajar menggunakan Pembelajaran Berbasis Masalah mampu melatih siswa lebih aktif, saat proses pembelajaran berlangsung.

2) Perancangan (Design) 
Tahap perancangan (design) bertujuan untuk merancang bahan ajar pembelajaran tematik terpadu kelas V SD menggunakan Pembelajaran Berbasis Masalah. Berdasarkan analisis pada tahap analisis maka dilakukan perancangan terhadap bahan ajar pembelajaran tematik terpadu yang sesuai dengan KI dan KD pembelajaran yang telah ditetapkan Kurikulum. Dari KD dijabarkan beberapa indikator, setelah itu bahan ajar dirancang sesuai dengan tahapan model Pembelajaran Berbasis Masalah.

Dalam penyusunan bahan ajar ini dimodifikasi dari struktur bahan ajar menurut Depdiknas yang terdiri atas; (1) cover, (2) kata pengantar, (3) daftar isi, (4) petunjuk penggunaan, (5) standar kompetensi lulusan dan kompetensi inti, (6) judul subtema dan pemetaan kompetensi dasar, (7) pemetaan indikator, (8) tujuan pembelajaran, (9) langkahlangkah Pembelajaran Berbasis Masalahdalam bahan ajar, (10) latihan siswa, (11) penilaian, (12) daftar pustaka.

\section{3) Pengembangan (Development)}

Tahap pengembangan ini bertujuan untuk menghasilkan bahan ajar Pembelajaran Berbasis Masalahyang valid, praktis dan efektif, sehingga layak digunakan dalam proses pembelajaran. Tahap pengembangan ini terdiri atas tiga tahap yaitu tahap validasi, tahap revisi dan tahap uji coba.. Hasil penilaian dari validator terhadap instrumen pengumpul data dinyatakan sangat valid karena rata-rata berkisar dari $81,42 \%$ sampai dengan $88,57 \%$, dapat disimpulkan instrumen penggumpul data penelitian sudah dapat digunakan untuk menvalidasi RPP, bahan ajar, keterlaksanaan RPP, respon guru, respon siswa, observasi penggunaan bahan ajar, dan aktivitas siswa. Berdasarkan validasi dari validator maka diperolehlah nilai di mana rata-rata untuk setiap pernyataan pada validasi RPP adalah berkisar dari $82,14 \%$ sampai $94,64 \%$ berada pada kategori sangat valid, apabila kita pisahkan berdasarkan aspek yang dinilai maka aspek identitas maka rata-ratanya adalah 90,10\% dengan kategori sangat valid, artinya aspek identitas pada RPP telah ditulis dengan lengkap sesuai dengan penulisan RPP yang diminta kurikulum. Aspek yang dinilai berikutnya adalah perumusan indikator di mana rata-rata kevalidanya adalah $89,29 \%$ dengan kategori sangat valid, aspek perumusan tujuan dengan rata-rata kevalidan $88,09 \%$ dengan kategori sangat valid, pemilihan materi pembelajaran dengan rata-rata $89,29 \%$ dengan kategori sangat valid, pemilihan sumber dan media pembelajaran dengan rata-rata $90,82 \%$ dengan kategori sangat valid, penyusunan kegiatan pembelajaran, mendapatkan rata-rata $88,65 \%$ dengan kategori sangat valid, penilaian di mana rata-ratanya adalah $91,07 \%$ dengan kategori sangat valid, Rata-rata keseluruhan hasil validasi RPP oleh validator dapat dilihat hasil validasi RPP secara keseluruhan dengan rata-rata $89,62 \%$ dengan kategori sangat valid,

Bahan ajar yang dirancang kemudian divalidasi oleh validator. Validasi dilakukan oleh tiga orang validator ahli dari perguruan tinggi dan empat orang validator praktisi dari kepala sekolah guru sekolah dasar. Pada kegiatan ini, pakar diminta untuk menilai bahan ajar yang sudah dibuat. Penilaian mencakup isi, penyajian, bahasa dan kegrafikaan.Validator diminta untuk memberikan penilaian serta saran perbaikan terhadap bahan ajar yang telah dirancang. Secara umum hasil validasi bahan ajar untuk aspek kelayakan isi dapat rata-rata untuk setiap pernyataan antara 85,71\% s/d 89,29\% yang berada pada kategori sangat valid. Kemudian untuk rata-rata validitas keseluruhan 
pada aspek kelayakan isi ini adalah $87,49 \%$ dengan kategori sangat valid. Ini berarti, isi bahan ajar telah menunjukkan kesesuaian antara isi dengan $\mathrm{KI}$ dan $K D$, perkembangan siswa, kebutuhan bahan ajar, kebenaran substansi materi dan telah memberikan penambah wawasan kepada siswa. Selain itu bahan ajar sesuai dengan Pembelajaran Berbasis Masalah, bahan ajar menyajikan permasalahan yang dekat dengan siswa, mengorganisasikan siswa dengan kelompok, membimbing penyelidikan individu atau kelompok, mengembangkan dan menyajikan hasil karya serta menganalisis atau mengevaluasi hasil pemecahan masalah.Penilaian bahan ajar berikutnya ditinjau dari aspek kebahasaan. Hasil validasi dari aspek kebahasaan mempunyai rentang nilai antara $85,71 \mathrm{~s} / \mathrm{d} 92,86 \%$ yang berada pada kategori sangat valid. Sedangkan untuk rata-rata validitas aspek kebahasaan secara keseluruhan adalah $90 \%$ dengan kategori sangat valid. Dengan demikian dapat dikatakan bahwa bahasa yang digunakan pada bahan ajar telah sesuai dengan kaidah bahasa Indonesia yang baik dan benar (EYD), penggunaan bahan ajar jelas, bahasa yang digunakan sederhana, lugas dan mudah dipahami serta bersifat komunikatif dan interaktif.

Uji Coba Pengembangan Bahan Ajar Tematik Terpadu Kelas V SD Menggunakan Pembelajaran Berbasisi Masalah

\section{a. Hasil Observasi Pelaksanaan Pembelajaran}

Observasi pelaksanaan pembelajaran bertujuan untuk melihat penggunaan bahan ajar tematik terpadu yang telah dirancang dalam proses pembelajaran, observasi dilakukan oleh peneliti. Berikut merupakan uraian hasil observasi pelaksanaan pembelajaran menggunakan bahan ajar tematik terpadu menggunakan Pembelajaran Berbasis Masalah di kelas V SDN 19 Kampung Baru.

Data observasi terlaksananya pembelajaran diambil dari lembar observasi terlaksananya RPP yang diperoleh observer pada setiap kali pertemuan. Hasil observasi pelaksanaan pembelajaran mencakup kegiatan awal, inti dan akhir sesuai dengan langkah-langkah Pembelajaran Berbasis Masalah dengan rata-rata 91,43\% termasuk dalam kategori sangat praktis. Berdasarkan hasil persentase pelaksanaan pembelajaran tersebut, secara umum sudah terlaksana sesuai rencana.

\section{b. Hasil Angket Praktikalitas untuk Guru}

Angket respon guru diberikan untuk mengetahui pendapat guru terhadap bahan ajar yang telah disusun. Analisis data yang diperoleh dari masing-masing angket respon guru terhadap praktikalitas bahan ajar berada pada kategori sangat praktis yaitu dengan persentase kepraktisan 93,05\%.

c. Hasil Angket Praktikalitas untuk Siswa

Angket respon siswa diberikan kepada siswa untuk mengetahui pendapat tentang tingkat kepraktisan bahan ajar. Angket respon siswa diisi oleh 40 orang siswa pada akhir uji coba. Secara ringkas hasil lembar praktikalitas terhadap angket respon siswa kelas Vb SDN 19 Kampung Baru Pariaman menunjukkan nilai kepraktisan yang berada pada rentang $84,72 \% \mathrm{~s} / \mathrm{d} 94,44 \%$ yang termasuk ke dalam kategori sangat praktis. Dengan demikian diperoleh persentase kepraktisan dari hasil angket respon siswa adalah $89,58 \%$.

\section{d. Hasil Observasi Penggunaan Bahan Ajar}


Observasi penggunaan bahan ajar dilakukan dengan melihat aktivitas siswa pada saat menggunakan bahan ajar yang dikembangkan. Terdapat beberapa aspek yang diamati, di antaranya adalah (1) siswa mudah memahami berbagai konsep yang ada pada bahan ajar, (2) siswa mudah memahami langkah-langkah kegiatan yang ada pada bahan ajar, (3) siswa tertarik dan termotivasi untuk belajar dari desain bahan ajar yang ditampilkan, dan (4) siswa aktif dan antusias mengerjakan tugas-tugas yang ada pada bahan ajar.

\section{4) Implementasi (Implementation)}

Tahap implementasi merupakan tahap penyebaran penggunaan bahan ajar yang telah dikembangkan pada sekolah lain. Pada penelitian ini, penyebaran dilakukan di SDN 08 Kampung Jawa Pariaman. Adapun tujuan dari tahap ini adalah untuk menguji efektivitas penggunaan bahan ajar yang dikembangkan pada objek dan kondisi yang berbeda.

Untuk menguji efektivitas bahan ajar pada tahap penyebaran ini, dilakukan hal yang sama seperti pada saat menguji keefektifan di tahap pengembangan, yaitu dengan melakukan penilaian aktivitas dan penilaian hasil berupa tes pemahaman yang diberikan di akhir subtema.

\section{5) Evaluasi (Evaluation)}

Pada tahap evaluasi ini merupakan tahap terakhir pada pengembangan bahan ajar kelas V SD menggunakan Pembelajaran Berbasis Masalah, dimana evaluasi yang dilakukan adalah evaluasi formatif dan evaluasi sumatif. Menurut Tegeh (2014: 43) "evaluasi formatif dilakukan untuk mengumpulkan data pada setiap tahap yang digunakan untuk penyempurnaan sedangkan evaluasi sumatif dilakukan pada akhir program untuk mengetahui pengaruhnya terhadap hasil belajar siswa dan kualitas pembelajaran secara luas"

Penelitian ini merupakan penelitian pendidikan dengan model design research yang mengembangkan suatu produk. Model pengembangan yang digunakan dalam penelitian ini diadaptasi dari Penelitian ini menggunakan model ADDIE. Menurut Tegeh (2014: 42) menyatakan model ADDIE terdiri dari lima tahap, yaitu: (1) analisis (analyze), (2) perancangan (design), (3) pengembangan (development), (4) implementasi (implememtation), dan (4) evaluasi (evaluation) .

Produk yang dikembangkan dalam penelitian ini adalah Bahan Ajar Tematik Terpadu kelas V SD menggunakan Pembelajaran Berbasis Masalah. Produk tersebut telah diuji cobakan pada siswa kelas Vb SDN 19 Kampung Baru Pariaman dan telah disebarkan pada siswa kelas $V$ SDN 08 Kampung Jawa Pariaman dengan jumlah siswa 40 dan 31 orang.

Bahan ajar tematik terpadu menggunakan Pembelajaran Berbasis Masalah dirancang serta digunakan oleh guru dan siswa pada tema 4 Sehat itu Penting, subtema Pola Hidup Sehat di kelas V Sekolah Dasar. Paparan pembahasan mengenai hasil penelitian pengembangan yang telah dilakukan akan diuraikan lebih lanjut validitas, praktikalitas, dan efektivitas produk yang dikembangkan.

\section{PENUTUP}


Penelitian ini adalah penelitian pengembangan bahan ajar tematik terpadu kelas $V$ SD menggunakan Pembelajaran Berbasis Masalahpada tema 4 subtema 2. Berdasarkan pengembangan, uji coba, dan penyebaran yang dilakukan, peneliti dapat menyimpulkan beberapa hal, sebagai berikut:

1. Bahan ajar menggunakan Pembelajaran Berbasis Masalah yang dihasilkan pada penelitian pengembangan ini sangat valid dari segi isi yaitu $87,49 \%$ segi kebahasaan $90 \%$, segi penyajian $88,56 \%$ dan segi kegrafikan $91,07 \%$.

2. Bahan ajar menggunakan Pembelajaran Berbasis Masalah yang dihasilkan pada penelitian pengembangan ini telah dapat dinyatakan sangat praktis dari hasil analisis respon guru yaitu dengan rata-rata 93,05\%, dan aspek respon siswa dengan rata-rata $89,58 \%$.

3. Bahan ajar menggunakan Pembelajaran Berbasis Masalah yang dihasilkan pada penelitian pengembangan ini telah dinyatakan efektif dilihat dari aktivitas dan hasil belajar. Aktivitas siswa dapat dilihat dari hasil pengamatan siswa pada saat uji coba dengan rata-rata $85,67 \%$ pada saat penyebaran menjadi $88,71 \%$ terdapat pada kategori sangat aktif. Hasil belajar siswa terdiri atas 3 aspek yaitu sikap, pengetahuan dan keterampilan. Pada aspek sikap saat uji coba diperoleh kategori sudah baik. Pada aspek pengetahuan saat uji coba diperoleh persentase ketuntasan 90,73 dan pada saat penyebaran menjadi 90,02. Pada aspek keterampilan saat uji coba diperoleh rata-rata 81,70 dan pada saat penyebaran 84,27 berada pada kategori baik.

\section{DAFTAR PUSTAKA}

Dwicahyono, Aris. 2014. Pengembangan Perangkat Pembelajaran (Silabus, RPP, PHB, Bahan Ajar). Yogyakarta: Gava Media.

Kemendikbud. 2014. Materi Pelatihan Guru Implementasi Kurikulum 2013 Tahun 2014 SD Kelas V. Jakarta: PSDMPK-PMP.

Mulyasa E. 2006. Kurikulum Yang Disempurnakan. Bandung: Remaja Rosdakarya.

Prastowo, Andi. 2013. Pengembangan Bahan Ajar Tematik. Jogyakarta: Diva Press

Rusman. 2010. Model-model Pembelajaran Mengembangkan Profesionalisme Guru. Jakarta: Rajagrafindo Persada.

Sanjaya, Wina. 2006. Strategi Pembelajaran Berorientasi Standar Proses Pendidikan. Jakarta: Kencana Prenada Media.

Satyosari, Punaji. 2015. Metode Penelitian Pendidikan \& Pengembangan. Jakarta: Prenadamedia Group.

Sugiyono. 201 2. Metode Penelitian Pendidikan Pendekatan Kuantitatif, Kualitatif, dan R\&D. Bandung: Alfabeta.

Trianto. 2010. Model Pembelajaran Terpadu (Konsep, Strategi, dan Implementasinya dalam Kurikulum Tingkat Satuan Pendidikan). Jakarta: Bumi Aksara. 